\title{
Pelvimetry in bitches N.R.D. (no race defined)
}

\author{
Pelvimetria em cadelas S.R.D. (sem raça definida)

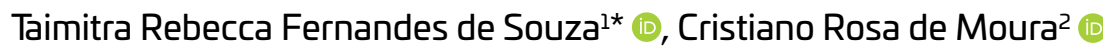

\begin{abstract}
Pelviology means the study of the pelvis, a structure formed by bones, ligaments and muscles. One of the subjects of pelviology corresponds to pelvimetry, which deals with the measurement of pelvic measurements, and which has a close relationship with reproduction. This study aims to verify the correlation between some body parameters and pelvic measurements. We used 50 N.R.D. female canine cadavers, varying in age and size, from euthanasia or natural death from the HOVET of UNIDESC and Veterinary Clinics of the cities of Valparaíso, Goiás-GO and Santa Maria-FD. Initially the body length, body height, thoracic perimeter, and body weight parameters were measured. Then, the bony pelvis was removed from the cadaver, sectioning the spine at the level between the lumbar vertebrae 5 (L5) and 6 (L6) and the femur in its middle third. Immediately after this procedure, the excess soft tissue was removed. In pelvimetry the following diameters were measured: thigh bone; transverse; acetabular; lateral ischiatic; true conjugate and vertical. The following mean values and standard deviation were obtained: 1) Body parameters: body weight $(\mathrm{Kg})-8.40 \pm 5.86$; height $(\mathrm{cm})-35.50 \pm 11.76$; body length $(\mathrm{cm})-48.60 \pm 13.48$; and thoracic perimeter $(\mathrm{cm})-43.80 \pm 14.24$; and 2) Pelvic diameters $(\mathrm{cm})$ : thigh bone -3.313 \pm 0.830 ; transversal $-3.864 \pm 0.900$; acetabular $-4.326 \pm 1.140$; lateral ischiatic $-7.171 \pm 2.140$; true conjugate -4.720 \pm 1.270 ; and vertical $-4.697 \pm 1.270$. Finally, it was verified that there is a significant positive correlation between body parameters and pelvic diameters.
\end{abstract}

KEYWORDS: canines; pelvic diameters; pelviology; body parameters.

RESUMO: A pelviologia corresponde ao estudo da pelve, estrutura formada por ossos, ligamentos e músculos. Um dos assuntos abordados da pelviologia corresponde a pelvimetria que trata da mensuração das medidas pélvicas, e a qual possui intima relação com a reprodução. O presente estudo tem por objetivo verificar a correlação entre alguns parâmetros corporais e as medidas pélvicas. Foram utilizados 50 cadáveres caninos fêmeas S.R.D., idade e tamanho variados, oriundos de eutanásia ou morte natural do HOVET do UNIDESC e Clínicas Veterinárias das cidades de Valparaíso, Goiás (GO) e Santa Maria (DF). Inicialmente mensurou-se os parâmetros corporais comprimento corporal; altura corporal; perímetro torácico e peso corporal. Em seguida, a pelve óssea foi retirada do cadáver, seccionando-se a coluna vertebral em nível entre as vértebras lombares 5 (L5) e 6 (L6) e o fêmur em seu terço médio, logo após esse procedimento retirou-se o excesso de tecidos moles. Na pelvimetria mensurou-se os diâmetros: coxal; transversal; acetabular; isquiático lateral; verdadeiro conjugado e vertical. Obteve-se os seguintes valores médios e desvio padrão: 1) Parâmetros corporais: peso corporal $(\mathrm{Kg})-8,40 \pm 5,86$; altura $(\mathrm{cm})-35,50 \pm 11,76$; comprimento corporal (cm) $48,60 \pm 13,48$; e perímetro torácico $(\mathrm{cm})-43,80 \pm 14,24$; e 2) Diâmetros pélvicos $(\mathrm{cm})$ : coxal - 3,313 $\pm 0,830$; transversal $3,864 \pm 0,900$; acetabular $-4,326 \pm 1,140$; isquiático lateral $-7,171 \pm 2,140$; conjugado verdadeiro $-4,720 \pm 1,270$; e vertical 4,697 $\pm 1,270$. Por fim, verificou-se que há correlação positiva significativa entre os parâmetros corporais e os diâmetros pélvicos.

PALAVRAS-CHAVE: caninos; diâmetros pélvicos; pelviologia; parâmetros corporais.

\section{INTRODUCTION}

Pelviology corresponds to the study of the pelvis. According to Oliveira et al. (2003) the Latin word pelvis has the same meaning in English, and conceptually, it corresponds to an osteoligamentous complex of multiple functions.

The pelvis is a structure formed by a group of bones arranged in a circular shape serving as an articulation of the pelvic limbs with the vertebral column. The pelvis has three bones on each side, which make up the thigh bone, namely, ilium, ischium and pubis. (ARAÚJO et al., 2014).
The bony pelvis constitutes the birth canal and at a complicated moment can be an impediment to birth. Thus, the pelvic cavity, from the ceiling to the floor, has a significant importance (ARAÚJO et al., 2014).

A complete discrimination of the bony pelvis and its particularities in domestic animals, is performed in most of the literature regarding veterinary anatomy; however, some do not make reference to pelvic diameters and, in their majority, do not present metric values (OKUDA et al., 1994a). 
The pelvic area can be understood as an important factor influencing the difficulty of delivery, the so-called dystocia, and it is largely the result of a fetal-pelvic incongruence, depending on the size of the fetus and the opening of the maternal pelvis or small pelvic cavity (DEUTSCHER, 1978; JOHNSON et al., 1988; MEIJERING, 1984; NIX et al., 1998 apud OLIVEIRA; GHELLER, 2009).

Dystocia can be conceptualized as difficult birth or the inability to expel the fetus through the birth canal without assistance (OLUWATOYIN; FAYEMI, 2011). Dystocia in bitches is a common occurrence in veterinary practice. Its frequency in the canine population is lower than 5\%; however, in some breeds it can reach values between $50-100 \%$. Thus, knowledge of pelvic measurements becomes important in obstetrics, which can be a factor of difficulty to expel the fetus (LINDEFORSBERG, 2002 apud PÁFARO, 2007).

Pelvimetry consists of measuring pelvic dimensions, and is correlated with reproduction (FERREIRA, 1991 apud NAVARRO, 2014). Pelvimetry allows the evaluation of maternal pelvic conformations, which can prevent difficulties in delivery, cesarean sections, or the death of mother and fetus at birth (KO; RUBLE, 1990; MEIJERING, 1984 apud OLIVEIRA; GHELLER, 2009).

In cattle, it has been proven that dystocia can be accurately prevented from data on pelvic dimensions and fetal weight (CLOETE et al., 1998)

In the case of internal pelvimetry, there are authors that prove the significant positive correlations between weight and external pelvic measurements, as well as the fact that the pelvimetry is influenced by the weight of the animal, which has a high correlation with the thoracic perimeter (PÁFARO, ISOLA, CANOLA, 2010).

According to Páfaro (2007) there are several methods for performing the pelvimetry, including radiography, internal and external in vivo pelvimetry, and the one performed on the anatomical parts of wild animals.

The present study aims to evaluate in cadavers of dogs with no race defined (N.R.D.) the pelvimetric measurements, the body parameters, and the existence of correlation between these two sets of data.

\section{METHOD}

The study was approved by the Ethics Commission on the Use of Animals (CEUA, in Portuguese) of the ICESP University Center in Brasilia, under protocol number AP03619.

Fifty N.R.D. female canine cadavers, with varying age and size, were used. The animals came from euthanasia and natural death from the HOVET of the CentroOeste University Development Center (UNIDESC) and Veterinary Clinics of the cities of Valparaíso, Goiás-GO and Santa Maria-FD. The cadavers were sent to the Animal Pathology Laboratory of UNIDESC where they were processed experimentally.
At the beginning of the experiment, the following measurements were performed for each cadaver: 1) body length (measure obtained from the occipitoatlantic transition to the base of the tail); 2) body height (measure obtained from the ground to the level of the junction between the right and left scapular bones); and 3) thoracic perimeter (measured at the junction between the right and left scapular bones, near the armpits to the xiphoid cartilage). Such measurements were obtained with a tape measure and the body weight of the cadaver was measured on a mechanical scale.

After the above-mentioned measurement procedure, the bony pelvis (thigh bone, sacral bone, and the first three coccygeal vertebrae) was removed from the cadaver, sectioning the spine at the level between lumbar vertebrae number 5 (L5) and 6 (L6), and the femur in its middle third. Then, the excess soft tissue was removed with great care to preserve the characteristics of the bony pelvis for the execution of the pelvimetry. The soft tissue residues removed, and the carcasses were frozen and discarded by the Animal Pathology Laboratory through the UNIDESC Solid Waste Disposal Program.

For the pelvimetry, a Starret ${ }^{\circledR}$ universal type pachymeter was used, and as reference, we used the study by Páfaro (2007), which measured the following pelvic diameters (Figure 1):

1) thigh diameter, horizontal distance between the two iliac tuberosities;

2) transverse diameter, horizontal distance between the bodies of the ilia in their middle third;

3) acetabular diameter, horizontal distance between the inner face of the two acetabular cavities; and

4) lateral ischiatic diameter, horizontal distance between the two lateral tuberosities of the ischium. It was also used as reference for measurements of the pelvis, Godinho et al. (1983), who highlight the following (Figure 2):

1) true conjugate diameter, distance between the sacral promontory and the cranial end of the pelvic symphysis; and

2) vertical diameter, distance between the cranial end of the pelvic symphysis and the pelvic cavity ceiling.

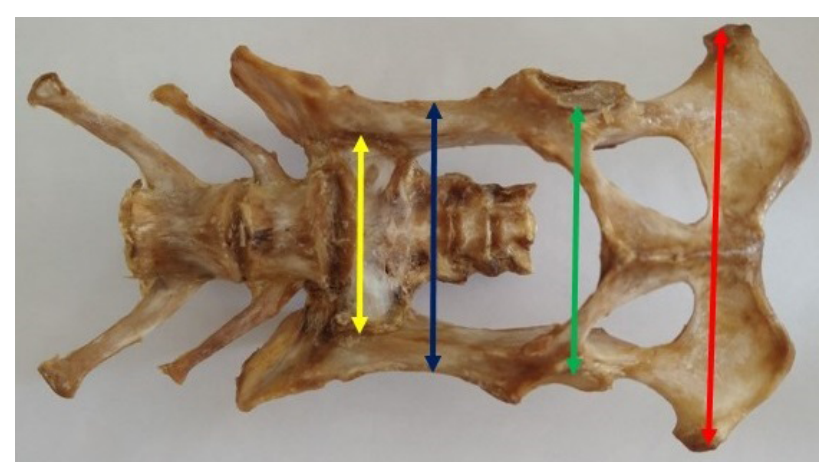

SOURCE: Author's collection.

Figure 1. Ventrodorsal view of the bony pelvis of N.R.D. bitches. Thigh diameter (yellow); transverse diameter (blue); acetabular diameter (green); and lateral ischiatic diameter (red). 
The results of pelvic diameter measurements were analyzed and statically treated by calculating the mean, standard deviation and median, as well as the correlation calculations between pelvic dimensions and body measurements, using the Microsoft ${ }^{\circledR}$ Office Excel application.

\section{RESULTS}

The results obtained from the measurements of body parameters and pelvimetry are presented in Table 1 . The evaluation of the correlation between these two data sets is presented in Table 2.

From the data presented in Table 2, there is a significant positive correlation between all body parameters and all pelvic diameters.

\section{DISCUSSION}

In general, when studying pelvimetry, the data are generalized and without further specifications in terms of age, size, weight or race of the animals used for the descriptions, which is in fact a common practice in textbooks. On the other hand, we also do not know whether such assessments were made in vivo or on macerated pieces (OKUDA et al., 1994a).

In our research we chose to work with female canines without a defined breed (N.R.D.) differently from the consulted authors who worked with the specific Boston Terrier and Scottish Terrier breeds (ENEROTH et al., 1999); Brazilian Fila, German Shepherd, Pinscher, Poodle, Rottweiler and Teckel (PÁFARO, 2007) and French Bulldog (CAMPOS, 2010). We can also highlight authors who have worked with other species, namely, cattle (OKUDA et al., 1994b); buffalo herds (OLIVEIRA et al., 2001); primates (VALLE et al., 2006; PINHEIRO et al., 2016); cats (PÁFARO et al., 2007; MONTEIRO et al., 2013) and anteaters (MARTINS et al., 2018).

Regarding age, in the present work we studied animals of various ages similar to those of Campos (2010); Páfaro (2007) and differently from (ENEROTH et al., 1999) who worked with adult animals.

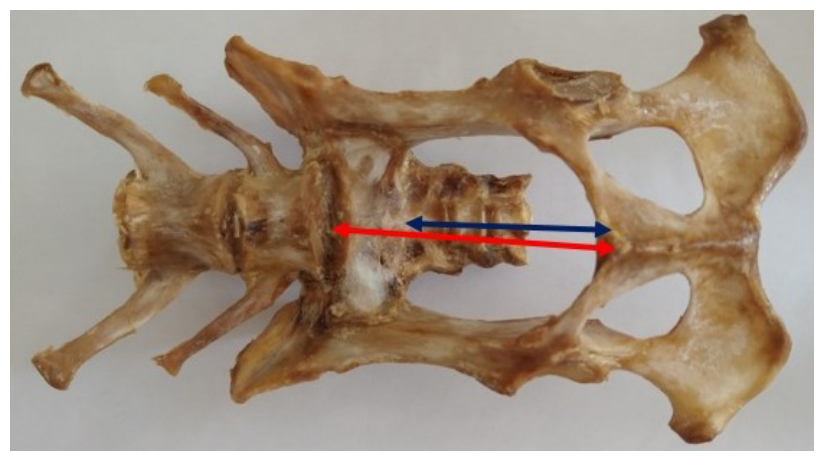

SOURCE: Author's collection.

Figure 2. Ventrodorsal view of the bony pelvis of N.R.D. Bitches. True conjugated diameter (red); and vertical diameter (blue).
In this trial, a sample of different breeds and ages was taken in order to provide a tool for a possible decision making on the part of the professional regarding a case related to obstetrics, where there was no possibility of a complementary imaging examination. This objective is also similar to those of Cloete et al. (1998); Verselino and Lopes (2005); Páfaro (2007); Oliveira and Gheller (2009); Páfaro, Isola, Canola (2010); Oluwatoyin and Fayemi (2011); Batilani et al. (2013) and Pinheiro et al. (2016).

Regarding the method for performing the pelvimetry, it is possible to use the $\mathrm{x}$-ray (XR), the pelvimetry in vivo internal and external and in anatomical parts (PÁFARO, 2007). In the present study, the pelvimetry was performed in anatomical pieces such as Martins et al. (2018), differently from Campos (2010); Eneroth et al. (1999); Monteiro et al. (2013); Páfaro (2007); Páfaro et al. (2007) and Pinheiro et al. (2016) that perform the pelvimetry from XR.

As for the mean, standard deviation and median values, the following values were obtained in the work developed. Body parameters: body weight $(\mathrm{Kg})-8.40 \pm 5.86$ and 6.85; body height $(\mathrm{cm})-35.50 \pm 11.76$ and 33.00; body length $(\mathrm{cm})-48.60 \pm 13.48$ and 48.00 ; and thoracic perimeter $(\mathrm{cm})-43.80 \pm 14.24$ and 41.80 . Pelvic diameters $(\mathrm{cm})$ : thigh $-3.313 \pm 0.830$ and 3.278 ; transverse $3.864 \pm 0.900$ and 4.025 ; acetabular $-4.326 \pm 1.140$ and 4.380; lateral ischiatic $-7.171 \pm 2.140$ and 7.203; true conjugate $-4.720 \pm 1.270$ and 4.735 ; and vertical -4.697 \pm 1.270 and 4.703 .

Eneroth et al. (1999) found in the Boston Terrier breed the mean value for pelvic radiographic measurements of bitches with normal delivery and with dystocia; they are, respectively: True conjugated diameter 4.5 and $4.4 \mathrm{~cm}$, vertical diameter 4.4 and $4.1 \mathrm{~cm}$, thigh diameter 7.1 and $6.9 \mathrm{~cm}$, transverse diameter 4.3 and $4.2 \mathrm{~cm}$, acetabular diameter 3.9 and 3.8 $\mathrm{cm}$, and lateral ischiatic diameter 7.2 and $7.3 \mathrm{~cm}$; and for the Scottish Terrier breed, true conjugated diameter 4.5 and 4.3 $\mathrm{cm}$, vertical diameter 4.6 and $4.3 \mathrm{~cm}$, thigh diameter 7.8 and $7.4 \mathrm{~cm}$, transverse diameter 4.3 and $4.3 \mathrm{~cm}$, and acetabular diameter 4.0 and $4.1 \mathrm{~cm}$.

Páfaro (2007) obtained the following means and standard deviations, respectively: Brazilian Breed, Thigh Diameter $(\mathrm{TD})=6.563 \pm 0.382 \mathrm{~cm}$, transverse diameter $(\mathrm{TRD})=6.666 \pm 0.400$ $\mathrm{cm}$, acetabular diameter $(\mathrm{AD})=8.630 \pm 0.463 \mathrm{~cm}$, and lat eral ischiatic diameter $(\mathrm{LID})=14.386 \pm 0.759 \mathrm{~cm}$; German Shepherd, TD $=6,410 \pm 0,406 \mathrm{~cm}, \mathrm{TRD}=6,542 \pm 0,411$ $\mathrm{cm}, \mathrm{AD}=8,417 \pm 0,649 \mathrm{~cm}$ and $\mathrm{LID}=13,340 \pm 0,894 \mathrm{~cm}$; Pinscher TD $=2.910 \pm 0.109 \mathrm{~cm}, \mathrm{TRD}=3.403 \pm 0.103$ $\mathrm{cm}, \mathrm{AD}=4.273 \pm 0.230 \mathrm{~cm}$ and $\mathrm{LID}=5.876 \pm 0.263 \mathrm{~cm}$; Poodle, TD $=3.486 \pm 0.475 \mathrm{~cm}, \mathrm{TRD}=3.902 \pm 0.645 \mathrm{~cm}$, $\mathrm{AD}=4.636 \pm 0.701 \mathrm{~cm}$, and LID $=6.718 \pm 1.086 \mathrm{~cm}$; Rottweiler, $\mathrm{TD}=6.236 \pm 0.441 \mathrm{~cm}, \mathrm{TRD}=6.356 \pm 0.418 \mathrm{~cm}, \mathrm{AD}=8.226 \pm 0.747$ $\mathrm{cm}$ and $\mathrm{LID}=12.896 \pm 0.856 \mathrm{~cm} ; \mathrm{NRD}, \mathrm{TD}=3.955 \pm 0.490$ $\mathrm{cm}, \mathrm{TRD}=4.332 \pm 0.516 \mathrm{~cm}, \mathrm{AD}=5.372 \pm 0.736 \mathrm{~cm}$ and 
Table 1. Body parameters and pelvimetric measurements of N.R.D. (No Defined Race) bitches, Luziânia-GO, 2020.

\begin{tabular}{|c|c|c|c|c|c|c|c|c|c|c|}
\hline OBS. & $B L(\mathrm{~cm})$ & BH $(\mathrm{cm})$ & $\mathrm{TP}(\mathrm{cm})$ & BW (Kg) & TD (cm) & $\begin{array}{l}\text { TRD } \\
(\mathrm{cm})\end{array}$ & $A D(\mathrm{~cm})$ & LID (cm) & $\begin{array}{l}\text { TCV } \\
(\mathrm{cm})\end{array}$ & VD $(\mathrm{cm})$ \\
\hline 1 & 74.0 & 60.0 & 81.0 & 22.2 & 3.995 & 4.190 & 4.365 & 9.530 & 6.295 & 6.405 \\
\hline 2 & 45.0 & 30.0 & 40.0 & 5.4 & 2.545 & 2.860 & 3.170 & 6.110 & 4.275 & 4.605 \\
\hline 3 & 46.0 & 39.0 & 38.5 & 5.1 & 2.870 & 3.545 & 4.005 & 7.140 & 4.745 & 4.705 \\
\hline 4 & 40.0 & 27.5 & 32.0 & 4.0 & 2.840 & 3.110 & 3.570 & 5.450 & 4.055 & 3.785 \\
\hline 5 & 37.0 & 25.5 & 30.0 & 3.0 & 2.345 & 2.580 & 2.765 & 4.680 & 3.595 & 3.570 \\
\hline 6 & 38.0 & 28.0 & 36.0 & 4.4 & 2.525 & 3.235 & 3.305 & 5.165 & 3.720 & 3.775 \\
\hline 7 & 63.0 & 45.5 & 49.0 & 10.6 & 4.505 & 5.135 & 6.185 & 9.175 & 5.920 & 6.505 \\
\hline 8 & 43.0 & 30.5 & 43.0 & 7.7 & 3.245 & 3.885 & 4.075 & 5.995 & 3.815 & 3.790 \\
\hline 9 & 53.0 & 29.5 & 43.5 & 7.8 & 3.270 & 4.125 & 4.520 & 7.030 & 4.640 & 4.920 \\
\hline 10 & 60.0 & 45.0 & 90.0 & 21.3 & 4.175 & 4.185 & 5.450 & 8.425 & 5.405 & 5.380 \\
\hline 11 & 56.0 & 39.0 & 54.0 & 15.7 & 3.990 & 4.415 & 5.140 & 8.145 & 5.565 & 5.340 \\
\hline 12 & 43.0 & 30.5 & 38.5 & 6.0 & 3.285 & 4.025 & 4.165 & 6.455 & 3.810 & 4.175 \\
\hline 13 & 28.0 & 20.0 & 28.5 & 2.3 & 2.170 & 2.695 & 2.645 & 4.735 & 3.075 & 3.115 \\
\hline 14 & 72.0 & 71.0 & 68.0 & 22.5 & 4.355 & 5.020 & 5.210 & 9.295 & 6.295 & 5.610 \\
\hline 15 & 48.0 & 39.0 & 42.0 & 7.4 & 3.265 & 3.325 & 3.685 & 7.135 & 5.265 & 4.835 \\
\hline 16 & 53.0 & 40.0 & 40.5 & 6.3 & 3.530 & 4.130 & 4.855 & 7.355 & 5.185 & 5.245 \\
\hline 17 & 32.0 & 24.0 & 30.0 & 2.7 & 2.695 & 2.940 & 3.190 & 5.110 & 3.265 & 4.045 \\
\hline 18 & 57.0 & 46.0 & 55.0 & 12.4 & 4.295 & 4.685 & 5.560 & 8.210 & 5.190 & 5.065 \\
\hline 19 & 54.0 & 42.0 & 48.0 & 9.8 & 3.570 & 4.110 & 4.690 & 8.445 & 4.895 & 5.005 \\
\hline 20 & 61.0 & 47.0 & 53.0 & 14.2 & 3.875 & 4.685 & 5.695 & 8.820 & 5.555 & 5.665 \\
\hline 21 & 48.0 & 35.0 & 36.0 & 4.9 & 2.815 & 3.545 & 4.280 & 7.265 & 4.805 & 4.880 \\
\hline 22 & 42.0 & 30.0 & 32.0 & 3.8 & 2.790 & 3.025 & 3.745 & 5.485 & 3.955 & 4.175 \\
\hline 23 & 33.0 & 27.0 & 28.0 & 3.0 & 1.860 & 2.645 & 2.785 & 4.805 & 3.135 & 2.920 \\
\hline 24 & 74.0 & 54.0 & 64.0 & 18.9 & 4.485 & 5.725 & 6.515 & 11.785 & 7.465 & 7.190 \\
\hline 25 & 52.0 & 37.0 & 49.0 & 10.0 & 3.525 & 4.690 & 5.230 & 8.285 & 5.040 & 5.555 \\
\hline 26 & 47.0 & 32.0 & 42.0 & 6.6 & 3.255 & 4.045 & 3.920 & 9.335 & 4.725 & 5.985 \\
\hline 27 & 34.0 & 23.0 & 30.0 & 2.9 & 2.305 & 2.505 & 2.920 & 4.605 & 3.290 & 2.775 \\
\hline 28 & 34.0 & 26.0 & 28.5 & 3.0 & 2.690 & 2.705 & 2.995 & 4.635 & 3.690 & 2.965 \\
\hline 29 & 51.0 & 31.0 & 41.5 & 8.2 & 3.770 & 4.270 & 4.725 & 7.745 & 4.765 & 4.265 \\
\hline 30 & 71.0 & 55.0 & 65.0 & 15.9 & 3.575 & 5.445 & 6.310 & 12.180 & 6.695 & 7.925 \\
\hline 31 & 40.0 & 27.0 & 36.0 & 3.5 & 2.885 & 2.985 & 4.495 & 3.335 & 2.855 & 3.180 \\
\hline 32 & 71.0 & 58.0 & 67.0 & 22.5 & 4.365 & 5.115 & 5.830 & 11.155 & 7.000 & 6.500 \\
\hline 33 & 58.0 & 33.0 & 48.0 & 11.2 & 4.340 & 4.690 & 4.890 & 8.630 & 4.555 & 4.920 \\
\hline 34 & 31.0 & 23.0 & 30.0 & 2.2 & 2.425 & 2.710 & 2.865 & 4.190 & 3.000 & 2.830 \\
\hline 35 & 48.0 & 35.0 & 35.0 & 4.5 & 3.095 & 3.445 & 3.745 & 7.635 & 4.810 & 4.700 \\
\hline 36 & 23.0 & 19.0 & 22.0 & 1.5 & 2.220 & 2.690 & 3.115 & 4.595 & 3.110 & 3.355 \\
\hline 37 & 35.5 & 21.0 & 26.0 & 1.9 & 2.445 & 2.655 & 2.820 & 4.685 & 3.440 & 2.965 \\
\hline 38 & 61.0 & 41.0 & 48.0 & 12.5 & 3.720 & 4.025 & 4.425 & 9.295 & 6.240 & 5.745 \\
\hline
\end{tabular}


Table 1. Continuation.

\begin{tabular}{|c|c|c|c|c|c|c|c|c|c|c|}
\hline OBS. & $B L(\mathrm{~cm})$ & BH $(\mathrm{cm})$ & $\mathrm{TP}(\mathrm{cm})$ & BW (Kg) & TD $(\mathrm{cm})$ & $\begin{array}{l}\text { TRD } \\
(\mathrm{cm})\end{array}$ & $A D(\mathrm{~cm})$ & LID $(\mathrm{cm})$ & $\begin{array}{l}\text { TCV } \\
(\mathrm{cm})\end{array}$ & VD $(\mathrm{cm})$ \\
\hline 39 & 23.0 & 14.0 & 24.0 & 1.3 & 1.695 & 2.315 & 2.255 & 3.015 & 2.520 & 2.375 \\
\hline 40 & 52.0 & 37.0 & 42.0 & 7.1 & 3.310 & 4.175 & 3.895 & 7.420 & 4.530 & 4.285 \\
\hline 41 & 44.0 & 31.0 & 38.0 & 5.5 & 3.305 & 4.010 & 3.775 & 6.655 & 3.285 & 3.305 \\
\hline 42 & 64.0 & 40.0 & 51.0 & 11.7 & 3.595 & 4.115 & 5.110 & 8.440 & 6.355 & 5.860 \\
\hline 43 & 44.0 & 31.0 & 40.0 & 7.1 & 3.715 & 4.155 & 4.765 & 7.875 & 4.255 & 4.385 \\
\hline 44 & 55.0 & 45.0 & 50.0 & 10.1 & 3.485 & 4.195 & 4.790 & 8.905 & 5.745 & 5.470 \\
\hline 45 & 71.0 & 57.0 & 67.0 & 17.1 & 6.480 & 6.235 & 7.830 & 11.345 & 8.365 & 7.590 \\
\hline 46 & 25.0 & 33.0 & 42.0 & 8.1 & 3.050 & 3.605 & 4.395 & 7.485 & 4.745 & 5.210 \\
\hline 47 & 48.0 & 23.0 & 40.0 & 7.6 & 3.110 & 3.810 & 4.520 & 5.820 & 4.355 & 4.385 \\
\hline 48 & 51.0 & 34.0 & 43.0 & 5.9 & 3.330 & 4.360 & 4.265 & 6.215 & 5.165 & 4.530 \\
\hline 49 & 45.0 & 27.0 & 39.0 & 6.1 & 3.215 & 3.910 & 4.445 & 6.945 & 4.305 & 4.360 \\
\hline 50 & 53.0 & 37.0 & 44.0 & 6.5 & 3.450 & 4.510 & 4.420 & 6.360 & 5.250 & 4.730 \\
\hline $\begin{array}{l}\text { Mean } \\
(\mathrm{cm})\end{array}$ & 48.60 & 35.50 & 43.80 & 8.40 & 3.313 & 3.864 & 4.326 & 7.171 & 4.720 & 4.697 \\
\hline $\mathrm{SD}$ & 13.48 & 11.76 & 14.24 & 5.86 & 0.830 & 0.900 & 1.140 & 2.140 & 1.270 & 1.270 \\
\hline $\begin{array}{l}\text { Median } \\
(\mathrm{cm})\end{array}$ & 48.00 & 33.00 & 41.80 & 6.85 & 3.278 & 4.025 & 4.380 & 7.203 & 4.735 & 4.703 \\
\hline
\end{tabular}

OBS. = Observation; $\mathrm{BL}=$ body length; $\mathrm{BH}=$ body height $\mathrm{TP}=$ thoracic perimeter; $\mathrm{BW}=$ body weight; $\mathrm{TD}=$ thigh diameter; $\mathrm{TRD}=$ transverse diameter; $A D=$ acetabular diameter; $L I D=$ lateral ischiatic diameter; $T C D=$ true conjugated diameter; $V D=$ vertical diameter; $S D=s t a n d a r d ~ d e v i a t i o n$. SOURCE: Author's collection.

Table 2. Correlação entre os parâmetros corporais e medidas pelvimétricas de cadelas S.R.D. (Sem Raça Definida), Luziânia-GO, 2020.

\begin{tabular}{l|c|c|c|c|c|c}
\hline Body Parameter & TD & TD & AD & LID & TCV & VD \\
\hline Body length & 0.883 & 0.893 & 0.880 & 0.924 & 0.967 & 0.902 \\
\hline Body height & 0.803 & 0.792 & 0.764 & 0.834 & 0.899 & 0.798 \\
\hline Thoracic perimeter & 0.796 & 0.721 & 0.727 & 0.775 & 0.801 & 0.739 \\
\hline Body weight & 0.841 & 0.780 & 0.764 & 0.804 & 0.853 & 0.747
\end{tabular}

$\mathrm{TD}=$ thigh diameter; $\mathrm{TD}$ = transverse diameter; $\mathrm{AD}$ = acetabular diameter; $\mathrm{LID}$ = lateral ischiatic diameter; $\mathrm{TCD}=$ true conjugated diameter; $\mathrm{VD}=$ vertical diameter.

SOURCE: Author's collection.

$\mathrm{LID}=8.235 \pm 1.218 \mathrm{~cm}$; and Dachshund, $\mathrm{TD}=3.896 \pm 0.285$ $\mathrm{cm}, \mathrm{TRD}=4.630 \pm 0.431 \mathrm{~cm}, \mathrm{AD}=5.670 \pm 0.450 \mathrm{~cm}$ and $\mathrm{LID}=7.866 \pm 0.563 \mathrm{~cm}$.

As for the issue of correlation between body parameters and pelvic diameters, we observed in this work a significant positive correlation between all body parameters, weight, height, length and thoracic perimeter, and all pelvic diameters, thigh, transverse, acetabular, lateral ischiatic, and true and vertical conjugate.

In his study on radiographic pelvimetry in French Bulldog bitches, Campos (2010) observed: Positive correlation between pelvic radiographic measurements of bi-ischial and thigh diameters and pelvic entry area and body weight, with a correlation index of 0.75 ; significant positive correlation between cranial circumference and sacral diameter, with a correlation index of 0.76; and the correlations between other external measurements and pelvic radiographic measurements were of low magnitude.

\section{CONCLUSION}

From the results obtained by the pelvimetric measurements and the body parameters one can conclude that:

1) the mean and standard deviation for body weight $(\mathrm{Kg})$ is $8.40 \pm 5.86$; for body height $(\mathrm{cm})$, it is $35.50 \pm 11.76$; for body length $(\mathrm{cm})$, it is $48.60 \pm 13.48$; and for the thoracic perimeter $(\mathrm{cm})$, it is $43.80 \pm 14.24$;

2) The mean and standard deviation for the thigh diameter $(\mathrm{cm})$ is $3.313 \pm 0.830$; for the transverse diameter $(\mathrm{cm})$, it is $3.864 \pm 0.900$; for the acetabular diameter $(\mathrm{cm})$, it is $4.326 \pm 1.140$; for the lateral ischial diameter $(\mathrm{cm})$, it 
is $7.171 \pm 2.140$; for the true conjugated diameter $(\mathrm{cm})$ and $4.720 \pm 1.270$; and for the vertical diameter $(\mathrm{cm})$, it is $4.697 \pm 1.270$.

Finally, it was verified that there is a significant positive correlation between body parameters and pelvic diameters, thus contributing with practical knowledge that can be used as tools by the veterinary obstetrician regarding the decision about a N.R.D. female dog dystocic delivery, since the literature on this group of animals does not address specific data on pelvimetry.

\section{ACKNOWLEDGMENTS}

The present work was supported and financed through the Institutional Program of Scientific Initiation Scholarships (PIBIC, in Portuguese) of the Centro-Oeste Development University Center (UNIDESC) / Interdisciplinary Research Center (NIP, in Portuguese).

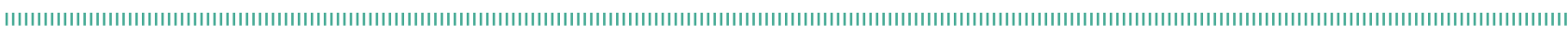
REFERENCES

ARAÚJO, A.A.O. et al. Pelvimetria de suínos das linhagens Agroceres e DanBred. Revista Brasileira de Ciência Veterinária, Niterói, v. 1, n. 4, p. 262-267, out./dez.2014. Disponível em: <https://periodicos.uff.br/rbcv/article/view/7313/5597>. Acesso em 01 fev. 2020.

BATILANI, S.; SANTOS, P.G.; LAZARETTI, R.M.J.; RIBEIRO, E.A. USO da pelvimetria na predição de distocia em cadelas. In: ENCONTRO INTERNACIONAL DE PRODUÇÃO CIENTÍFICA CESUMAR, 8. 2013, Maringá. Anais... Maringá: CESUMAR, 2013. Disponível em: <http://www.cesumar.br/prppge/pesquisa/epcc2013/oit_ mostra/Sandy_Batilani.pdf >. Acesso em 02 set. 2019.

CAMPOS, A.I.M. Estabelecimento padrão biométrico corpóreo e pélvico e da relação entre as medidas corpóreas externas e as medidas pelvimétricas de cadelas da raça Buldogue Francês. Fortaleza, 2010. 70 f. Dissertação (Mestrado em Ciências Veterinárias) - Universidade Estadual do Ceará, Fortaleza, 2010. Disponível em: <http://www.uece.br/ppgcvwp/wp-content/ uploads/sites/6/2019/08/iraina_dissertacao.pdf>. Acesso em: 01 fev. 2016

CLOETE, S.W.P. et al. Ease of birth relation to pelvic dimensions, litter weight and conformation of sheep. Small Ruminant Research, v. 31, n. 1, p. 51-60, dez, 1998. Disponível em: <http://www. sciencedirect.com/science/article/pii/SO921448898001199>. Acesso em: 01 fev. 2020.

ENEROTH, A. et al. Radiographic pelvimetry for assessment of dystocia in bitches: a clinical study in two terrier breeds. Journal of Small Animal Practice, v. 40, p. 257-264, jun., 1999. Disponível em: <https://doi.org/10.1111/j.1748-5827.1999. tb03076.x>. Acesso em 01 fev. 2020.

GODINHO, H.P.; CARDOSO, F.M.; NASCIMENTO, J.F. Anatomia dos ruminantes domésticos. Belo Horizonte. Universidade Federal de Minas Gerais, 1983. p 31

MARTINS, J.K.V.; SOARES, M.J.V.; CARVALHO, R.A.; TAVARES H.D.; ARANTES, R.C.; BOSSO, A.C.S. Pelvimetria e Pelviologia em Myrmecophaga tridactyla. In: CONGRESSO REGIONAL DE SANIDADE ANIMAL E SAÚDE PÚBLICA, 1./ SEMANA ACADÊMICA DE MEDICINA VETERINÁRIA 11., 2018, Araguaína-TO. Anais [...]. Araguaína-TO: UFT, 2018 p. 41. Disponível em: <http:// repositorio.uft.edu.br/bitstream/1 1612/1 153/1/1\%20 congresso\%2ORegional\%20de\%20Sanidade\%20Animal\%20 e\%20Sa\%C3\%BAde\%20P\%C3\%BAblica\%20e\%20xI\%20
Semana\%20Acad\%C3\%AAmica\%20de\%20Medicina\%20 Veterin\%C3\%A1 ria.pdf>. Acesso em 02 set. 2019.

MONTEIRO, C.L.B. et al. Pelvic differences between brachycephalic and mesaticephalic cats and indirect pelvimetry assessment. Veterinary Record, n. 5, jan., 2013. Disponível em: <https://www. researchgate.net/profile/Lucia_Silva3/publication/232765926_ Pelvic_differences_between_brachycephalic_and_ mesaticephalic_cats_and_indirect_pelvimetry_assessment/ links/02e7e52d592d870329000000>.pdf. Acesso em: 01 fev. 2020.

OKUDA, T.H. et al. Aspectos de pelvimetria e pelviologia em fêmeas de bovinos da raça Guzerá (Bos indicus - LINNAEUS, 1758). Brazilian Journal of Veterinary Research and Animal Science, São Paulo, v. 31, n. 3/4, p. 181-185, 1994a. Disponível em: <http://www.revistas.usp.br/bjvras/article/view/52062>. Acesso em: 01 fev. 2020.

OKUDA, T.H. et al. Influência do parto na pelvimetria de vacas guzerá. Revista da Faculdade de Zootecnia, Veterinária e Agronomia, Uruguaiana, v. 1, n. 1, p. 39-48, 1994b. Disponível em: <http://revistaseletronicas.pucrs.br/ojs/index.php/fzva/ article/viewFile/1938/1442>. Acesso em: 28 abr. 2016.

OLIVEIRA, A.C.; BOMBONATO, P.P.; BARUSELLF, P.S.; OLIVEIRA, S.F.J.; SOUZA, O.A. Pelvimetria e pelviologia em búfalas mestiças. Brazilian Journal of Veterinary Research and Animal Science, São Paulo, v. 38, n. 3, p. 114-121, apr 2001. Disponível em: <http://www.scielo.br/pdf/bjvras/v38n3/9690.pdf>. Acesso em: 01 fev. 2020.

OLIVEIRA, C.P.; BOMBONATO, P.P.; BALEIRO, J.C.C. Pelvimetria em vacas Nelore. Brazilian Journal of Veterinary Research and Animal Science, São Paulo, v. 40, n.4, p. 297-304, 2003. Disponível em: <https://www.scielo.br/scielo.php?script=sci_ arttext\&pid=S1413-95962003000400009>. Acesso em 01 fev. 2020.

OLIVEIRA, L.F., GHELLER, V.A. “Avaliação de medidas pélvicas internas de vacas holandesas do estado de minas gerais, Brasil." Ciência Animal Brasileira, Goiânia, supl. 1, p. 802-807, out. 2009. Disponível em: <https://www.revistas.ufg.br/vet/article/ view/7906/5759>. Acesso em: 01 fev. 2020.

OLUWATOYIN, A.O., FAYEMI, O.E. A survey on cases of dystocia in bitch at Southwestern Nigeria. Global Veterinária, v. 6, n. 1, 
p. 97-100, 2011. Disponível em: <https://www.idosi.org/gv/ gv6(1)11/13.pdf>. Acesso em 01 fev. 2020.

PÁFARO, V. Pelvimetria radiográfica em diferentes raças de fêmeas caninas adultas (Canis familiares - LINNAEUS, 1758). Jaboticabal, 2007. 38 f. Dissertação (Mestrado em Medicina Veterinária) - Universidade Estadual Paulista "Júlio de Mesquita Filho”, Jaboticabal. Disponível em: < https:// repositorio.unesp.br/bitstream/handle/1 1449/89013/ pafaro_v_me_jabo.pdf? sequence $=1$ \&isAllowed $=y>$. Acesso em: 01 fev. 2020.

PAFARO, V. et al. Pelvimetria radiográfica em fêmeas felinas. Acta Scientiae Veterinariae, Porto Alegre, v. 35 (supl. 2), p. s558-s559, 2007. Disponível em: <http://www.ufrgs.br/ actavet/35-suple-2/anclivepa\%20artigos\%20meios\%20 diagnostico.pdf >. Acesso em: 02 set. 2019.

PAFARO, V., ISOLA, J.G.M.P., CANOLA, J.C. A importância da pelvimetria radiográfica para a reprodução de animais de companhia e de produção: Revisão de literatura. PUBVET, Londrina, v. 4, n. 23, 2010. Disponível em: <http://www.pubvet.com.br/uplo ads/33913d3f64e8dbd923947ddb0691 129a.pdf>. Acesso em: 01 fev. 2020.

PINHEIRO, L.L. et al. X-ray pelvimetry in common marmoset (Callithrix jacchus - LINNAEUS, 1758). Arquivo Brasileiro de Medicina Veterinária e Zootecnia, Belo Horizonte, vol. 68, n. 3, p. 695-701, maio/jun. 2016. Disponível em: <https://dx.doi.org/10.1590/1678-4162-8508>. Acesso em: 30 jan. 2020.

VALLE, R.M.C et al. Pelvimetria em macacos da noite (Aotus azarai infulatus - KUHL, 1820). Brazilian Journal of Veterinary Research and Animal Science, São Paulo, v. 43, n. 3, p. 370378, 2006. Disponível em: <http://www.revistas.usp.br/bjvras/ article/view/26485/28268>. Acesso em: 01 fev. 2020.

VERSELINO, J.R.; LOPES, M.D. Pelvimetria para o Diagnóstico e Prevenção de Distocia em Cadelas: Revisão. MEDVEP Revista Científica de Medicina Veterinária - Pequenos Animais e Animais de Estimação, Curitiba, v. 3, n. 10, p. 132-136, 2005. Disponível em: <https://www.bvs-vet.org.br/ vetindex/periodicos/medvep-revista-cientifica-de-medicinaveterinaria-/3-(2005)-10/>. Acesso em: 02 set 2019. 